\title{
RADIOCARBON AND STABLE CARBON ISOTOPE ANALYSES OF LAND SNAILS FROM THE CHINESE LOESS PLATEAU: ENVIRONMENTAL AND CHRONOLOGICAL IMPLICATIONS
}

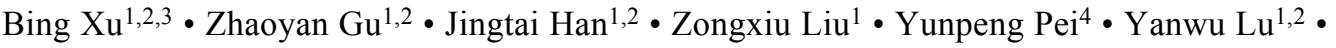 \\ Naiqin $\mathrm{Wu}^{1,2} \cdot$ Yongfu Chen ${ }^{1,2}$
}

\begin{abstract}
Paired radiocarbon and stable carbon analyses have been carried out on aragonite shells and organic soft bodies of snails from the Chinese Loess Plateau in order to explore the possibility of using these kinds of samples as environmental and chronological indicators. Results show that the soft bodies exhibit ${ }^{14} \mathrm{C}$ concentrations similar to those of plant leaves, indicating that carbon in the soft bodies is fixed from organic diets. The aragonite shells are depleted in ${ }^{14} \mathrm{C}$ compared to the soft bodies due to ingestion of ${ }^{14} \mathrm{C}$-depleted carbonate. This depletion shows a consistent pattern across the Chinese Loess Plateau, implying a good potential for the snail shells to be applicable for ${ }^{14} \mathrm{C}$ dating with a simple correction. The $\delta^{13} \mathrm{C}$ values measured for aragonite shells display a linear relationship with those obtained for the soft bodies with a constant offset. In addition, the carbon derived from organic diets accounts for more than $70 \%$ of the total shell carbon. This fact suggests that stable carbon isotope composition of aragonite shells mainly reflects that of organic diet, and could be used as a reliable indicator of paleodiet in the Chinese Loess Plateau.
\end{abstract}

\section{INTRODUCTION}

Land snail shells have been used in paleoenvironmental (Goodfriend and Ellis 2002; Stott 2002; Balakrishnan et al. 2005) and chronological (Mook and Vogel 1968; Magaritz and Heller 1980; Brennan and Quade 1997; Pigati et al. 2004; Mastronuzzi and Romaniello 2008) studies in the past decades. However, the environmental and chronological significance of aragonite shells is far from being understood because the sources and dynamics involved in the deposition of the aragonite shells needs to be further defined. Some authors indicate that organic diets are the major source and control the carbon isotope composition of the shell carbon (DeNiro and Epstein 1978; Goodfriend and Ellis 2002; Stott 2002; Balakrishnan et al. 2005). Magaritz et al. (1981) emphasize the land-air boundary $\mathrm{CO}_{2}$ in controlling the isotopic composition of the shell carbonate with a minor effect from diet. Radiocarbon studies suggest that carbonate carbon (most are ${ }^{14} \mathrm{C}$-depleted) also contribute to the shell formation (Goodfriend and Hood 1983; Goodfriend 1987; Pigati et al. 2004; Quarta et al. 2007; Romaniello et al. 2008).

The possible sources for the shell carbon, including atmospheric $\mathrm{CO}_{2}$, inorganic carbonate, and organic diets, have distinct ${ }^{14} \mathrm{C}$ and stable isotopic signatures. Thus, paired analysis of ${ }^{14} \mathrm{C}$ and stable carbon isotopes of the shell, organic bodies, and organic diets of the snail can provide valuable information on the processes and sources associated with the formation of aragonite shells, particularly for the definition of the proportions of the different sources, which has great significance for unraveling the paleoenvironmental and chronological implications of the carbon isotopes of snail shells. However, previous studies concentrate mostly on the carbon isotopes of snail shells, or stable carbon isotope alone.

In this study, the ${ }^{14} \mathrm{C}$ activities and $\delta^{13} \mathrm{C}$ of both the bodies and shells of living snails collected across the Chinese Loess Plateau were measured. The main object of this study is to evaluate the chronological and environmental significance of the aragonite shell in this region by estimating the proportions of the different carbon origins incorporated into the shells.

\footnotetext{
${ }^{1}$ Key Laboratory of Cenozoic Geology and Environment, Institute of Geology and Geophysics, Chinese Academy of Sciences, Beijing 10029, China.

${ }^{2}$ Institute of Geology and Geophysics, Chinese Academy of Sciences, Beijing 10029, China.

${ }^{3}$ Corresponding author. Email: bingx@mail.igcas.ac.cn.

${ }^{4}$ China University of Geosciences, Beijing 100083, China.
} 


\section{MATERIALS AND METHOD}

The live land snails were collected mainly from the Chinese Loess Plateau (Figure 1), and cover different geographic settings across the region in order to have a wide representation of the study area. Each sample consists of at least 40 individuals, thus reducing the effect of individual anomalies. After collection, living snails were drowned in boiled deionized water and the soft parts were separated from the shells using forceps. Shells were not powdered during pretreatment to minimize the potential for adsorption of atmospheric ${ }^{14} \mathrm{C}$ (Samos 1949). At the same time, the leaves of deciduous poplars were collected for determining the ${ }^{14} \mathrm{C}$ activity of atmospheric $\mathrm{CO}_{2}$. Nineteen samples, composed only of adult Cathaica, were selected for coupled stable and ${ }^{14} \mathrm{C}$ isotopic analysis because of its wide distribution and abundance over the loess plateau. For the other samples (30), only $\delta^{13} \mathrm{C}$ was analyzed.

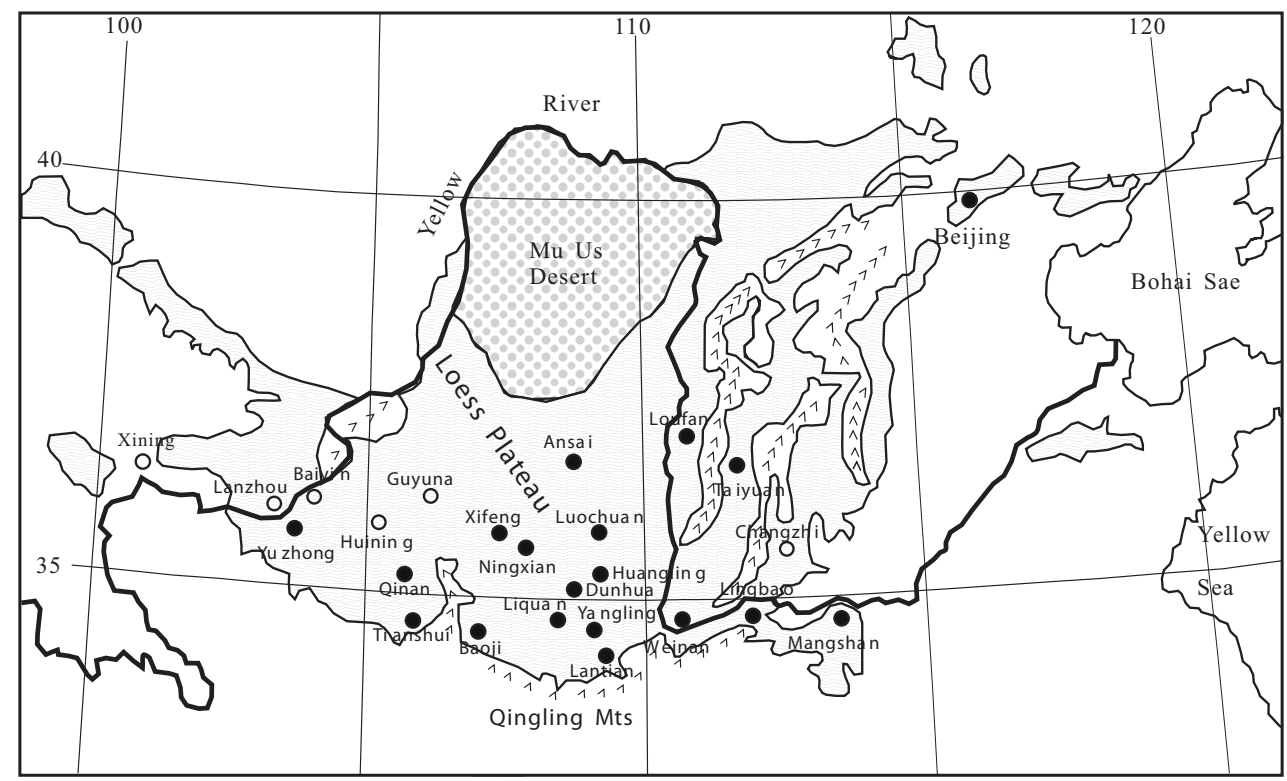

Figure 1 Locations of the sampling sites in the Chinese Loess Plateau. Filled circles represent the samples for both radiocarbon and stable carbon isotope analysis; empty circles indicate those only for $\delta^{13} \mathrm{C}$ analyses.

The live snail shells were treated with $6 \% \mathrm{NaOCl}$ for $48-72 \mathrm{hr}$ to remove organic matter, washed repeatedly, and sonicated for 5-10 min to remove adhering materials. The cleaned shells were briefly washed with diluted $\mathrm{HCl}$ to remove adhering carbonate, rinsed with distilled water, then dried using a filter vacuum, and dried further in a vacuum oven overnight at $70^{\circ} \mathrm{C}$.

The soft bodies, and plant leaves as well, were treated with $10 \% \mathrm{HCl}$ for $6 \mathrm{hr}$ at $25{ }^{\circ} \mathrm{C}$, washed repeatedly, sonicated for 5-10 min, dried using a filter vacuum, and further dried in a vacuum oven at $70{ }^{\circ} \mathrm{C}$ overnight. The dried soft bodies and leaves were crushed and amalgamated using a mortar and pestle for carbon isotopic analyses.

The ${ }^{14} \mathrm{C}$ activities of the snail shells and soft bodies were measured by liquid scintillation spectrometry with benzene as the scintillation solvent. The shells were converted into $\mathrm{CO}_{2}$ by acid hydrolysis by using $\mathrm{HCl}$ under vacuum, and the organic matter powder was combusted in an oxygen stream under a temperature of $900{ }^{\circ} \mathrm{C}$. The $\mathrm{CO}_{2}$ produced was purified, collected with liquid nitrogen, and then reacted with lithium under $800{ }^{\circ} \mathrm{C}$ to be converted into $\mathrm{Li}_{2} \mathrm{C}_{2}$. After cooling, $\mathrm{C}_{2} \mathrm{H}_{2}$ was obtained 
through hydrolysis of the $\mathrm{Li}_{2} \mathrm{C}_{2}$, and finally catalyzed into benzene. The benzene was then mixed with the scintillator, a mixture of MSB+Butyl PDB. ${ }^{14} \mathrm{C}$ activity was measured by liquid scintillation spectrometry (Quantulus ${ }^{\mathrm{TM}} 1220$ ).

For stable carbon isotope analysis, the powders of aragonite shells and organic matter (soft bodies and leaves) were reacted with $100 \%$ phosphoric acid and combusted offline, respectively. The $\mathrm{CO}_{2}$ produced was collected with liquid nitrogen, and isotopic ratios of ${ }^{13} \mathrm{C} /{ }^{12} \mathrm{C}$ were measured with a MAT 252 mass spectrometer. The isotopic data were reported in the conventional notation as per mil (\%) deviations relative to the PDB standard with uncertainties ( $1 \sigma$ ) of $\pm 0.1 \%$.

\section{RESULTS}

Carbon isotope compositions of the aragonite shells and soft bodies of the snail samples from the Chinese Loess Plateau are plotted in Figure 2. The stable isotopic composition of snail shells $\left(\delta^{13} \mathrm{C}_{\text {shell }}\right)$ varies from $-13.1 \%$ to $-4.3 \%$. The soft bodies have an isotopic value $\left(\delta^{13} \mathrm{C}_{\text {body }}\right)$ ranging from $-26.8 \%$ to $-18.1 \%$. The $\delta^{13} \mathrm{C}_{\text {shell }}$ displays a linear relationship with $\delta^{13} \mathrm{C}_{\text {body }}$ with an offset of $14.0 \pm 0.7 \%$ (Figure 2).

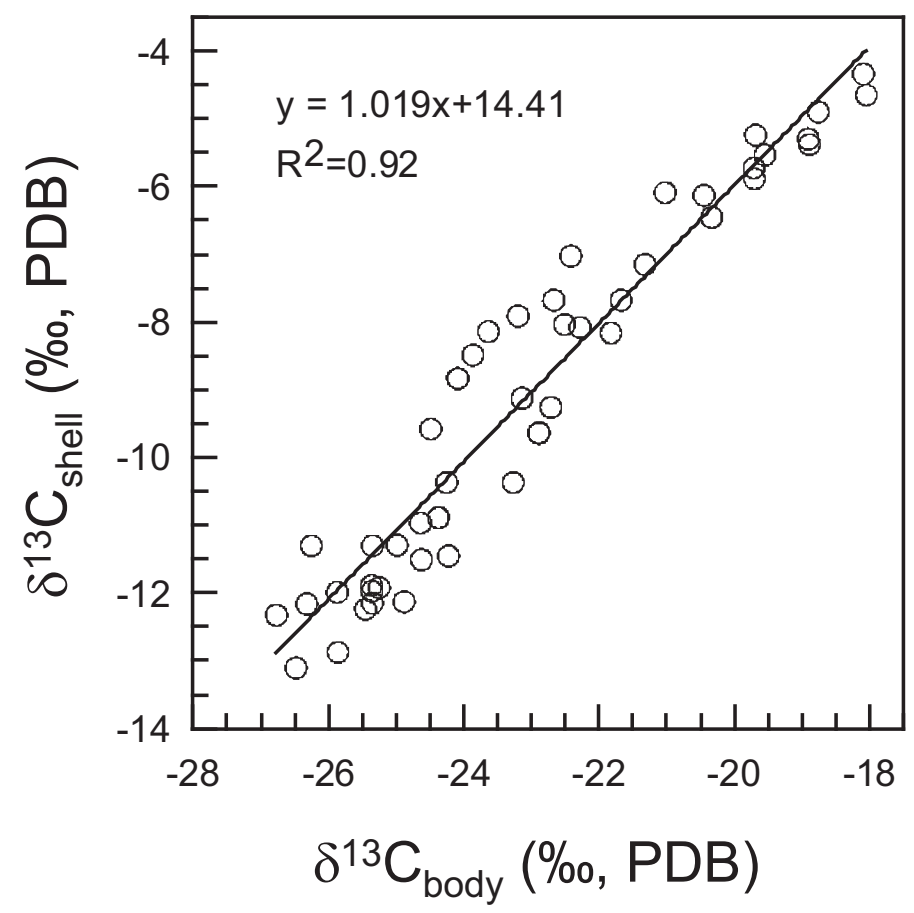

Figure 2 Stable carbon isotope relationship between aragonite shells and soft bodies of the living land snails from the Chinese Loess Plateau.

${ }^{14} \mathrm{C}$ activities of the snail soft bodies range from 106.40 to $108.89 \mathrm{pMC}$ with an average of $107.9 \pm$ $0.6 \mathrm{pMC}$. These results display no distinguishable difference from those measured for the tree leaves $(108.08 \pm 1.87 \mathrm{pMC}$; see Table 1$)$, indicating that the carbon isotope compositions of the snail bodies are derived from organic diets without discrimination. In contrast, the aragonite shells are depleted in ${ }^{14} \mathrm{C}(93.75-99.57 \mathrm{pMC})$ compared to the bodies (Table 1), suggesting a contribution of ${ }^{14} \mathrm{C}$-depleted carbonate to the shell. 
Table 1 Measured and calculated results for live snails across the Chinese Loess Plateau.

\begin{tabular}{|c|c|c|c|c|c|c|c|c|c|}
\hline Location & Species & $\delta^{13} \mathrm{C}_{\text {body }}$ & $\delta^{13} \mathrm{C}_{\text {shell }}$ & $A_{\text {shell }^{\mathrm{a}}}$ & $A_{\text {body }}{ }^{\mathrm{a}}$ & $\begin{array}{l}f_{\text {atm }} \\
(\%)\end{array}$ & $\begin{array}{l}f_{\text {calc }} \\
(\%)\end{array}$ & $\begin{array}{l}f_{\text {met }} \\
(\%)\end{array}$ & $\begin{array}{l}\text { Age } \\
\text { anomaly }\end{array}$ \\
\hline Yuzhong & C. cunlunensis & -21.7 & -7.7 & $95.50 \pm 0.70$ & $108.16 \pm 1.34$ & 20 & 17 & 64 & $1256 \pm 112$ \\
\hline Luochuan & C. pulveratrix & -24.3 & -10.4 & $96.44 \pm 0.71$ & $106.63 \pm 0.86$ & 14 & 12 & 74 & $1070 \pm 88$ \\
\hline Weinan & C. pulveratricula & -26.3 & -12.2 & $93.80 \pm 0.69$ & $106.40 \pm 1.29$ & 12 & 14 & 74 & $1285 \pm 114$ \\
\hline Mangshan & C. pulveratrix & -22.9 & -9.6 & $96.05 \pm 0.81$ & $108.25 \pm 1.27$ & 12 & 14 & 74 & $1211 \pm 116$ \\
\hline Taiyuan & C. pulveratrix & -21.3 & -7.2 & $98.28 \pm 0.92$ & $108.19 \pm 1.07$ & 21 & 12 & 67 & $1029 \pm 109$ \\
\hline Ansai & C. cunlunensis & -26.3 & -11.3 & $96.68 \pm 0.96$ & $107.12 \pm 1.13$ & 17 & 13 & 71 & $1106 \pm 116$ \\
\hline Beijing & C. pulveratrix & -22.3 & -8.1 & $95.77 \pm 0.87$ & $108.15 \pm 1.07$ & 20 & 14 & 66 & $1237 \pm 108$ \\
\hline Fenhe & C. pulveratrix & -25.4 & -12.0 & $93.75 \pm 0.89$ & $107.66 \pm 1.07$ & 9 & 15 & 76 & $1371 \pm 110$ \\
\hline Xifeng & C. pulveratricula & -22.4 & -7.0 & $97.83 \pm 0.91$ & $108.31 \pm 0.96$ & 27 & 13 & 60 & $1095 \pm 103$ \\
\hline Qinan & C. pulveratrix & -25.5 & -12.2 & $97.78 \pm 0.88$ & $108.20 \pm 0.97$ & 8 & 12 & 80 & $1071 \pm 102$ \\
\hline Huangling & C. pulveratricula & -23.9 & -8.5 & $98.35 \pm 0.88$ & $108.20 \pm 0.96$ & 24 & 12 & 64 & $1048 \pm 101$ \\
\hline Liquan & C. pulveratricula & -24.6 & -11.5 & $97.42 \pm 0.83$ & $107.89 \pm 0.94$ & 9 & 12 & 79 & $1074 \pm 98$ \\
\hline Ningxian & C. pulveratrix & -20.3 & -6.5 & $96.97 \pm 1.03$ & $108.88 \pm 0.93$ & 22 & 14 & 64 & $1181 \pm 109$ \\
\hline Tianshui & C. pulveratricula & -25.9 & -12.0 & $98.86 \pm 0.81$ & $108.00 \pm 1.04$ & 12 & 11 & 77 & $978 \pm 102$ \\
\hline Baoji & C. pulveratricula & -22.5 & -8.0 & $95.45 \pm 1.03$ & $107.93 \pm 1.03$ & 21 & 14 & 65 & $1252 \pm 116$ \\
\hline Yangling & C. pulveratricula & -24.4 & -10.9 & $96.06 \pm 0.84$ & $107.70 \pm 0.81$ & 11 & 13 & 76 & $1177 \pm 93$ \\
\hline Lantian & C. pulveratricula & -25.2 & -11.9 & $99.57 \pm 0.82$ & $107.32 \pm 1.05$ & 9 & 10 & 81 & $861 \pm 103$ \\
\hline Lingbao & C. pulveratricula & -23.1 & -9.1 & $95.34 \pm 0.92$ & $107.51 \pm 0.96$ & 16 & 14 & 70 & $1226 \pm 106$ \\
\hline Dunhua & C. pulveratricula & -24.1 & -8.8 & $95.39 \pm 0.88$ & $108.20 \pm 0.96$ & 22 & 15 & 63 & $1292 \pm 103$ \\
\hline Leaf & & -28.17 & & & $108.08 \pm 1.87$ & & & & \\
\hline
\end{tabular}

${ }^{\mathrm{a}} A$ uncorrected for isotopic fractionation; $\mathrm{PMC}=\%$ modern carbon (AD 1950).

\section{DISCUSSION}

The mass-balance model was often used to estimate the fractions of carbon of different origins and thus interpret the ${ }^{14} \mathrm{C}$ depletion in snail shells (Goodfriend and Hood 1983; Romaniello et al. 2008). This model is based on the following assumptions: 1) isotope fractionation occurs when atmospheric $\mathrm{CO}_{2}$ passes through the mantle into hemolymph, and the aragonite shell is deposited from bicarbonate pool; and 2) there is no fractionation between the metabolic $\mathrm{CO}_{2}$ and $\mathrm{HCO}_{3}{ }^{-}$pool. Based on this model, as suggested by Stott (2002), the $\delta^{13} \mathrm{C}$ of snail shells depends on the habits of snails, their dietary intake, and the $p \mathrm{CO}_{2}$ at ground level, and thus it would be difficult to interpret the $\delta^{13} \mathrm{C}$ of shells solely in terms of dietary intake. Obviously, this contradicts the linear relationship found between the $\delta^{13} \mathrm{C}$ of shells and bodies/diets of both cultured (DeNiro and Epstein 1978; Stott 2002; Metref et al. 2003) and field-collected snails (this study), and contradicts a number of observations that show the $\delta^{13} \mathrm{C}$ of land snail shell reflects the carbon isotope composition of their diets (Magaritz et al. 1981; Goodfriend and Ellis 2002; Balakrishnan et al. 2005).

In fact, the isotopic fractionations involving the metabolic $\mathrm{CO}_{2}$ fractionation can well explain the $\delta^{13} \mathrm{C}$ linear relationship and constant offset between the shells and bodies of the cultured snails (Stott 2002). The total fractionation between the metabolic $\mathrm{CO}_{2}$ and aragonite shells is $12.7 \%, 10 \%$ from the fractionation between the metabolic $\mathrm{CO}_{2}$ and $\mathrm{HCO}_{3}{ }^{-}$pool from which the shell is deposited (Mook et al. 1974; Zhang et al. 1995) and 2.7\%o from that between aragonite and bicarbonate pool (Rubinson and Clayton 1969). In our study, the average offset between the aragonite shells and soft bodies is around $14.0 \%$, which is close to the total isotopic fractionations between the metabolic $\mathrm{CO}_{2}$ and aragonite shells, supporting a significant fractionation between the metabolic $\mathrm{CO}_{2}$ and $\mathrm{HCO}_{3}{ }^{-}$pool that cannot be ignored during estimation of the proportions of the shell carbon with various origins.

Taking into account the mass balance, the following equations can be established: 


$$
\begin{gathered}
R_{\text {total }}=f_{\text {met }} R_{\text {met }}+f_{\text {calc }} R_{\text {calc }}+f_{\mathrm{atm}} R_{\mathrm{atm}} \\
f_{\text {met }}+f_{\text {calc }}+f_{\text {atm }}=1
\end{gathered}
$$

where $R$ and $f$ are the ${ }^{13} \mathrm{C} /{ }^{12} \mathrm{C}$ or ${ }^{14} \mathrm{C} /{ }^{12} \mathrm{C}$ ratio and carbon fraction, respectively, and the subscripts total, met, calc, and atm represent respectively the integrate, metabolic, soil carbonate (mostly calcite), and atmospheric carbon sources for the $\mathrm{CO}_{2}-\mathrm{H}_{2} \mathrm{O}-\mathrm{CaCO}_{3}$ system in the snail body fluid from which the shell is deposited.

In the $\mathrm{CO}_{2}-\mathrm{H}_{2} \mathrm{O}-\mathrm{CaCO}_{3}$ system, the carbon isotopic ratio is dominated by $\mathrm{HCO}_{3}{ }^{-}$and $\mathrm{CO}_{2}$ including gaseous and dissolved phases. When isotopic fractionation reaches equilibrium, there is

$$
R_{\text {total }}=f R_{\mathrm{HCO}_{\overline{3}}^{-}}+(1-f) R_{\mathrm{CO}_{2}}=R_{\mathrm{HCO}_{3}^{-}}\left(f+\frac{1-f}{\alpha}\right)
$$

where $\alpha$ is the average value of fractionation factors between $\mathrm{HCO}_{3}{ }^{-}$and dissolved and gaseous $\mathrm{CO}_{2}\left(\approx\left(\alpha_{\mathrm{CO}_{2} \text { (aq.) }}^{\mathrm{HCO}_{-}^{-}}+\alpha_{\left.\mathrm{CO}_{2} \text { (gas.) }\right)}^{\mathrm{HCO}_{-}^{-}}\right) / 2\right)$, and $R_{\mathrm{HCO}_{3}^{-}}$and $R_{\mathrm{CO}_{2}}$ are the carbon isotopic ratios for $\mathrm{HCO}_{3}^{-}$ and $\mathrm{CO}_{2}$ in the system, respectively. $f$ is the molar fraction of $\mathrm{HCO}_{3}{ }^{-}$.

In the system $\mathrm{CO}_{2}-\mathrm{H}_{2} \mathrm{O}-\mathrm{CaCO}_{3}$, there are 2 moles of $\mathrm{HCO}_{3}{ }^{-}$for every 1 mole of $\mathrm{Ca}^{2+}$ at normal $\mathrm{pH}$. Therefore, the molar concentration of $\mathrm{Ca}\left(f_{\mathrm{Ca}}\right)$ is only half that of $\mathrm{HCO}_{3}{ }^{-}(f)$, i.e. $f_{\mathrm{Ca}}=1 / 2(f)$, or $f=$ $2 f_{\mathrm{Ca}}\left(\right.$ and $\left.f=2 f_{\text {calc }}\right)$. Thus, Equation 3 becomes

$$
R_{\text {total }}=R_{\mathrm{HCO}_{3}^{-}}\left(2 f_{\text {calc }}+\frac{1-2 f_{\text {calc }}}{\alpha}\right)
$$

Combing Equations 1 and 4, we get Equation 5:

$$
R_{\mathrm{HCO}_{3}^{-}}=\alpha \frac{f_{\mathrm{met}} R_{\mathrm{met}}+f_{\text {calc }} R_{\text {calc }}+f_{\text {atm }} R_{\text {atm }}}{1+2 f_{\text {calc }}(\alpha-1)}
$$

Introducing $\delta^{13} \mathrm{C}_{\text {sample }}=\left(\frac{R_{\text {sample }}}{R_{\text {sample }}}-1\right) \times 1000$, Equation 5 then becomes

$$
\delta{ }^{13} \mathrm{C}_{\mathrm{HCO}_{3}^{-}}+1000=\alpha_{13} \frac{f_{\text {met }} \delta \delta^{13} \mathrm{C}_{\text {met }}+f_{\text {calc }} \delta \delta^{13} \mathrm{C}_{\text {calc }}+f_{\text {atm }} \delta^{13} \mathrm{C}_{\mathrm{atm}}+1000}{1+2 f_{\text {calc }}\left(\alpha_{13}-1\right)}
$$

where $\alpha_{13}$ stands for the ${ }^{13} \mathrm{C}-{ }^{12} \mathrm{C}$ fractionation factor. At $20{ }^{\circ} \mathrm{C}, \alpha_{13}=1.0091$ (Mook et al. 1974) and $\delta^{13} \mathrm{C}_{\mathrm{HCO} 3}{ }^{-}=\delta^{13} \mathrm{C}_{\text {shell }}-2.7$ (Mook and Vogel 1968; Rubinson and Clayton 1969), where $\delta^{13} \mathrm{C}_{\text {shell }}$ is the measured isotope composition of the snail shell. $\delta^{13} \mathrm{C}_{\mathrm{met}}$ can be obtained by measuring the $\delta^{13} \mathrm{C}$ of the soft bodies $\left(\delta^{13} \mathrm{C}_{\text {body }}\right) \cdot \delta^{13} \mathrm{C}_{\text {atm }}$ is taken as $-8 \%$ (Wahlen 1994). $\delta^{13} \mathrm{C}_{\text {calc }}$ is the value of carbonates in the surface soil of the Chinese Loess Plateau.

Introducing $A_{\text {sample }}={ }^{14} \mathrm{C} /{ }^{12} \mathrm{C}$ for the ${ }^{14} \mathrm{C}$ activity, we modify Equation 5 as follows:

$$
A_{\mathrm{HCO}_{3}^{-}}=\alpha_{14} \frac{f_{\text {met }} A_{\text {met }}+f_{\text {calc }} A_{\text {calc }}+f_{\text {atm }} A_{\text {atm }}}{1+2 f_{\text {calc }}\left(\alpha_{14}-1\right)}
$$

where $\alpha_{14}$ stands for the ${ }^{14} \mathrm{C}-{ }^{12} \mathrm{C}$ fractionation factor and $\alpha_{14} \approx \alpha_{13}{ }^{2}$ (Wigley and Muller 1981). $A_{\mathrm{HCO}_{3}^{-}}, A_{\text {met }}, A_{\text {atm }}$, and $A_{\text {calc }}$ are ${ }^{14} \mathrm{C}$ activities of the $\mathrm{HCO}_{3}^{-}$pool, metabolic and atmospheric $\mathrm{CO}_{2}$, 
and soil carbonate, respectively. Since old carbonate is completely ${ }^{14} \mathrm{C}$-depleted in most cases, $A_{\text {calc }}=0$ can be applied in Equation 7. $A_{\mathrm{HCO}_{3}^{-}}=(1+0.0027)^{-2} A_{\text {shell }}, A_{\text {shell }}$ and $A_{\text {met }}$, and $A_{\text {met }}$ are the measured ${ }^{14} \mathrm{C}$ activities of shells and bodies $\left(A_{\text {body }}\right)$.

As the carbon isotopic values of the carbonate in surface soil $\left({ }^{13} \delta_{\text {calc }}\right),{ }^{14} \mathrm{C}$ activities, and carbon isotopic ratios can be obtained from previous work or measurement, the terms $f_{\text {atm }}, f_{\text {met }}$, and $f_{\text {calc }}$ become known through resolving the combined Equations 2, 6, and 7. According to Gu et al. (1991), the ${ }^{13} \delta_{\text {carb }}$ of the surface soil ranges from $-3 \%$ to $-9 \%$, with an average of $-6 \%$ in the Chinese Loess Plateau. In this study, the average value is used for ${ }^{13} \delta_{\text {carb }}$. This could cause a $1-2 \%$ shift for the calculated $f_{\text {atm }}$ and $f_{\text {met }}$, but no effect for $f_{\text {calc }}$ is observed.

The calculated results of the different carbon sources are presented in Table 1. The shell carbon is dominated by its ingested diet, which accounts for $60-81 \%$. The fractions from atmospheric $\mathrm{CO}_{2}$ vary from $8 \%$ to $27 \%$; the proportions of carbon originated from carbonate display a narrow variation with an average of $13 \pm 2 \%$. These results suggest that the organic diet is the main contributor for the shell carbon.

Concerning ${ }^{14} \mathrm{C}$, estimating the proportion of ${ }^{14} \mathrm{C}$-depleted carbonate in the snail shells allows calculation of the corresponding age anomaly. In order to calculate the age anomaly, fractionation correction of the $A_{\text {shell }}$ term is necessary. The fractionation-corrected $A_{\text {corrected }}$ term can be calculated from the measured term $\left(A_{\text {measured }}\right)$ by using the standard formula of Stuiver and Polach (1977):

$$
A_{\text {corrected }}=A_{\text {measured }}\left[1-\frac{2\left(\delta^{13} \mathrm{C}+25\right)}{1000}\right]
$$

This equation is valid only for the component of shell carbon derived directly or indirectly from atmospheric $\mathrm{CO}_{2}$ (Pigati 2003). Therefore, Equation 8 should be

$$
A_{\text {corrected }}=A_{\text {measured }}\left[1-\frac{2\left(\delta^{13} \mathrm{C}_{\mathrm{nlc}}+25\right)}{1000}\right]
$$

where $\delta^{13} \mathrm{C}_{\mathrm{nlc}}$ is the carbon isotope of the shell carbonate derived from non-carbonate sources. Substituting $\delta^{13} \mathrm{C}_{\mathrm{HCO}^{-}}{ }^{-}=\delta^{13} \mathrm{C}_{\text {shell }}-2.7$ and $\alpha_{13}=1.0091$ in Equation 6, the following is obtained

$$
\delta^{13} \mathrm{C}_{\text {shell }}=\frac{f_{\text {met }}\left(1.0091 \delta^{13} \mathrm{C}_{\text {met }}+11.8\right)+f_{\text {atm }}\left(1.0091 \delta^{13} \mathrm{C}_{\mathrm{atm}}+11.8\right)+f_{\text {calc }}\left(1.0091 \delta^{13} \mathrm{C}_{\text {calc }}-6.35\right)}{1+2 f_{\text {calc }}(1.0091-1)}
$$

and the proportion of the contribution of the non-carbonate sources $(P)$ is

$$
P=\frac{f_{\mathrm{met}}\left(1.0091 \delta^{13} \mathrm{C}_{\mathrm{met}}+11.8\right)+f_{\mathrm{atm}}\left(1.0091 \delta^{13} \mathrm{C}_{\mathrm{atm}}+11.8\right)}{f_{\mathrm{met}}\left(1.0091 \delta^{13} \mathrm{C}_{\mathrm{met}}+11.8\right)+f_{\mathrm{atm}}\left(1.0091 \delta^{13} \mathrm{C}_{\mathrm{atm}}+11.8\right)+f_{\mathrm{calc}}\left(1.0091 \delta^{13} \mathrm{C}_{\mathrm{calc}}-6.35\right)}
$$

Thus, Equation 9 becomes

$$
A_{\text {corrected }}=A_{\text {shell }}\left[1-\frac{2\left(P_{\mathrm{nlc}} \delta^{13} \mathrm{C}_{\text {shell }}+25\right)}{1000}\right]
$$

$P_{\text {nlc }}$ displays a rather consistent variation across the Chinese Loess Plateau, ranging from the 0.71 to 0.86 , with an average of $0.79 \pm 0.04$. Therefore, the fractionation correction can be reduced to 


$$
A_{\text {corrected }}=A_{\text {shell }}\left[1-\frac{2\left(0.79 \delta^{13} \mathrm{C}_{\text {shell }}+25\right)}{1000}\right]
$$

and the age anomalies $(\Delta)$ can be calculated by

$$
\Delta=-8033 \ln \left(\frac{A_{\text {shell }[}\left[1-\frac{2\left(0.79 \delta^{13} \mathrm{C}_{\text {shell }}+25\right)}{1000}\right]}{A_{\text {atm }}}\right)
$$

The results in Table 1 show that the age anomalies range from $860 \pm 66$ to $1371 \pm 134 \mathrm{yr}$. The measured age anomalies are rather convergent $(1148 \pm 127 \mathrm{yr})$, demonstrating that the ${ }^{14} \mathrm{C}$ of the Cathaica shells has the potential for chronological application after a simple correction in the Chinese Loess Plateau. The convergent ${ }^{14} \mathrm{C}$ age anomalies of the shell carbonate across the Chinese Loess Plateau might be associated with the similarities of both the ecological habits of the studied snails and the calcium sources. According to Goodfriend (1987), the age anomalies correspond closely with the ecology of the snails, and the difference in availability of calcium for shell growth. Snails with a continual availability of calcium for growth do not need to take up as large an amount of carbonate as plant-dwelling species, to which carbonate is available only by ground feeding (Goodfriend 1987), and have less ${ }^{14} \mathrm{C}$-depletion of the shell carbonate. In our study, the samples for ${ }^{14} \mathrm{C}$ analysis are composed of the same species, Cathaica, which should have similar ecological habits. Likewise, topsoil in the Chinese Loess Plateau, which has uniform origination and is enriched in calcium minerals, can provide a continual supply of calcium for snail growth. As pointed out by Pigati (2003) and Quarta et al. (2007), the age anomaly correction can result in a significant enlargement of uncertainty, which may limit its applications for higher chronological precision, such as archaeological chronology.

\section{CONCLUSION}

The stable and ${ }^{14} \mathrm{C}$ isotope composition of aragonite shells and soft bodies of the Cathaica collected in different sites of the Chinese Loess Plateau have been analyzed in order to estimate the possible carbon sources, paleovegetation and chronological implications of the shells. The ${ }^{14} \mathrm{C}$ activities of snail bodies cannot be discriminated from that of the plant leaves. The ${ }^{14} \mathrm{C}$ activities of shell aragonite are significantly lower than those measured for bodies, indicating the incorporation of ${ }^{14} \mathrm{C}$ depleted carbon from carbonate into the shell. The age anomalies of the shells caused possibly by ingested carbonate concentrated around $1148 \pm 127 \mathrm{yr}$, suggesting the potential of the Cathaica shell for chronological application in the Chinese Loess Plateau. The $\delta^{13} \mathrm{C}$ of shell aragonite displays a linear relationship with the carbon isotopic composition of bodies with a constant offset of $14.0 \%$. The fractions of the different carbon sources in snail shells have been estimated by a model, which considers both mass balance and isotope fractionations between different carbon phases during the formation of the snail shells. The results show that the fraction of the carbon from organic diets accounts for $60-81 \%$, and the proportions of the carbon from carbonate and atmospheric $\mathrm{CO}_{2}$ ranges from $8 \%$ to $27 \%$ and $10 \%$ to $17 \%$, respectively, indicating the shell $\delta^{13} \mathrm{C}$ of the Cathaica in the Chinese Loess Plateau mainly reflect that of organic diets. 


\section{ACKNOWLEDGMENTS}

We owe thanks to Prof Fusong Zhang for stable carbon analysis and to Prof Kazimierz Rozanski for his constructive advice and language polishing. This study was financially supported by NSFC (40672118 and 40673072).

\section{REFERENCES}

Balakrishnan M, Yapp CJ, Theler JL, Carter BJ, Wyckoff DG. 2005. Environmental significance of ${ }^{13} \mathrm{C} /{ }^{12} \mathrm{C}$ and ${ }^{18} \mathrm{O} /{ }^{16} \mathrm{O}$ ratios of modern land-snail shells from the southern Great Plains of North America. Quaternary Research 63(1):15-30.

Brennan R, Quade J. 1997. Reliable late-Pleistocene stratigraphic ages and shorter groundwater travel times from ${ }^{14} \mathrm{C}$ in fossil snails from the southern Great Basin. Quaternary Research 47(3):329-36.

Deniro MJ, Epstein S. 1978. Influence of diet on distribution of carbon isotopes in animals. Geochimica et Cosmochimica Acta 42(5):495-506.

Goodfriend GA. 1987. Radiocarbon age anomalies in shell carbonate of land snails from semi-arid areas. Radiocarbon 29(2):159-67.

Goodfriend GA, Ellis GL. 2002. Stable carbon and oxygen isotopic variations in modern Rabdotus land snail shells in the southern Great Plains, USA, and their relation to environment. Geochimica et Cosmochimica Acta 66(11):1987-2002.

Goodfriend GA, Hood DG. 1983. Carbon isotope analysis of land snail shells: implications for carbon sources and radiocarbon dating. Radiocarbon 25(3):810-30.

Gu ZY. 1991. The carbonate isotopic composition of the loess-paleosol sequence and its implication of paleoclimatic change. Chinese Science Bulletin 36(23): 1979-83.

Magaritz M, Heller J. 1980. A desert migration indicator-oxygen isotopic composition of land snail shells. Palaeogeography, Palaeoclimatology, Palaeoecology 32(1-2):153-62.

Magaritz M, Heller J, Volokita M. 1981. Land-air boundary environment as recorded by the ${ }^{18} \mathrm{O} /{ }^{16} \mathrm{O}$ and ${ }^{13} \mathrm{C} /$ ${ }^{12} \mathrm{C}$ isotope ratios in the shells of land snails. Earth and Planetary Science Letters 52(1):101-6.

Mastronuzzi G, Romaniello L. 2008. Holocene aeolian morphogenetic phases in southern Italy: problems in ${ }^{14} \mathrm{C}$ age determinations using terrestrial gastropods. Quaternary International 183(1):123-34.

Metref S, Rousseau D-D, Bentaleb I, Labonne M, Vianey-Liaud M. 2003. Study of the diet effect on $\delta^{13} \mathrm{C}$ of shell carbonate of the land snail Helix aspersa in experimental conditions. Earth and Planetary Science Letters 211(3-4):381-93.

Mook WG, Vogel JC. 1968. Isotopic equilibrium between shells and their environment. Science 159(3817):8745 .

Mook WG, Bommerson JC, Staverman W. 1974. Carbon isotope fractionation between dissolved bicarbonate and gaseous carbon-dioxide. Earth and Planetary Science Letters 22(2):169-76.

Pigati JS. 2003. On correcting ${ }^{14} \mathrm{C}$ ages of gastropod shell carbonate for fractionation. Radiocarbon 44(3):75560.

Pigati JS, Quade J, Shahanan TM, Haynes CV Jr. 2004. Radiocarbon dating of minute gastropods and new constraints on the timing of late Quaternary springdischarge deposits in southern Arizona, USA. Palaeogeography, Palaeoclimatology, Palaeoecology 204(1-2):33-45.

Quarta G, Romaniello L, D’Elia G, Mastronuzzi G, Calcagnile L. 2007. Radiocarbon age anomalies in preand post-bomb land snails from the coastal Mediterranean Basin. Radiocarbon 49(2):817-26.

Romaniello L, Quarta G, Mastronuzzi G, D'Elia M, Calcagnile L. 2008. C-14 age anomalies in modern land snails shell carbonate from Southern Italy. Quaternary Geochronology 3(1-2):68-75.

Rubinson M, Clayton RN. 1969. Carbon-13 fractionation between aragonite and calcite. Geochimica et Cosmochimica Acta 33(8):997-1002.

Samos G. 1949. Some observations on exchange of $\mathrm{CO}_{2}$ between $\mathrm{BaCO}_{3}$ and $\mathrm{CO}_{2}$ gas. Science $110(2868)$ : 663-5.

Stott LD. 2002. The influence of diet on the $\delta^{13} \mathrm{C}$ of shell carbon in the pulmonate snail Helix aspersa. Earth and Planetary Science Letters 195(3-4):249-59.

Wahlen M. 1994. Carbon dioxide, carbon monoxide and methane in the atmosphere: abundance and isotopic composition. In: Rundel PW, Ehleringer JR, Nagy KA, editors. Stable Isotopes in Ecology and Environmental Science. New York: Springer. p 93-113.

Wigley TML, Muller AB. 1981. Fractionation corrections in radiocarbon dating. Radiocarbon 23(2):17390.

Zhang J, Quay PD, Wilbur DO. 1995. Carbon isotope fractionation during gas-water exchange and dissolution of $\mathrm{CO}_{2}$. Geochimica et Cosmochimica Acta 59(1): $107-14$. 